\title{
Ecotoxicology of sediment in the estuary of the Jundiaí and Potengi Rivers in Natal-RN, Brazil, by using Leptocheirus plumulosus as test-organism
}

\author{
Lopes, R.B.; Souza, R.F.; Silva-Nicodemo, S.C.T.; Cruz, J.V.F. \& Medeiros, G.F. \\ Universidade Federal do Rio Grande do Norte
}

Received December 13, 2017; Accept June 03, 2018

\begin{abstract}
The estuary of the Potengi and Jundiaí Rivers is situated on the coast of the state of Rio Grande do Norte, Brazil, and has a record of contamination by metals and organic contaminants. However, there are few studies regarding the toxic effects of pollution on the aquatic organisms from this area. The objective was to assess the quality of sediments from the Jundiaí and Potengi Rivers, by the use of toxicity tests with the amphipod Leptocheirus plumulosus. The sediments were collected from 4 sites, in 4 different months along 2011. After data analysis, it was possible to observe that the sediments collected close to the most populated areas of Macaíba and Natal (P1 and P3) were toxic. Sediment from the Station 4 did not show toxicity in any of the months studied, despite its urban location near the port of Natal. This result might be related to a low level of organic matter and greater tidal influence, which affect the dilution of the contaminants at this area and can reduce the sediment toxicity. No relationship between rainfall and environmental toxicity was observed.
\end{abstract}

Keywords: Ecotoxicological tests, Estuarine complex, Amphipoda - Crustacea, Heavy metals.

\section{INTRODUCTION}

The estuary of the Jundiai/Potengi Rivers (JPR) is one of the main estuaries in the state of Rio Grande do Norte and extends for approximately $25 \mathrm{~km}$, varying between 400 and $600 \mathrm{~m}$ wide. The estuary is formed by the waters of the Potengi, Jundiaí and Doce Rivers. Various activities developed along the estuary surroundings have contributed to the influx of metals into this body of water. Literature reports to anthropogenic input of organic contamination (Souza, 2017) and metals in sediments for cadmium, copper, lead, chromium, nickel and zinc (Guedes, 2003; Sindern et al., 2007; Lima et al., 2010) as well as the level of metals in biomarkers (Silva et al., 2006; Emerenciano, 2008; Brito et al., 2008; Lopes et al., 2013). Because of the concentrations of metals related to anthropogenic activities in sediments from JPR, ecotoxicological studies should be performed to evaluate the possible effects of these contaminants on aquatic organisms. Moreover, the National Council for the environment - CONAMA Resolution 454/2012, article
12, indicates ecotoxicological tests for sediments with concentrations of mercury, cadmium, lead, arsenic higher than the level 1. These tests measure the toxic effects of the bioavailable fractions present in the sediment under controlled laboratory conditions or field tests (Araújo et al., 2008).

Silva-Nicodemo (2010) evaluated the toxicity of effluents (Hospital wastewater, shrimp farming, sewer, immunizing and industrial effluents) in Potengi River estuary on Mysidopsis juniae (Mysidacea-Crustacea), and concluded that many of the effluents were toxic to the survival and reproduction of this organism. In samples of effluent-receiving bodies (Baldo Channel, the Lavadeiras Creek and Macaíba Creek), the overall mortality occurred after 24 hours exposure. According to the author all effluents analyzed, with the exception of some effluent from harvest, caused effects on the survival of M. juniae, being the more toxic the effluent treatment stationETS Quintas (LC50, 5,85\%), ETS Aerated Lagoon (LC50, 6.24), Giselda Trigueiro Hospital (LC50, 2.05) and dairying CLAN (LC50, 2.14). There are toxicity studies record of toxicity tests with sediment samples collected along the 
estuarine environment of the JPR (BURUAEM et al., 2013; SOUZA et al. 2016).

Leptocheirus plumulosus has been used in sediment toxicity studies with various contaminants, such as metals, DDT and sewage (McGee et al., 1998; McGee et al., 1999; Lotufo et al., 2001; Zulkosky et al., 2002; Yu \& Fleeger, 2006; Williams et al., 2010, Manyin \& Rowe, 2006; McGee et al., 2004). Bertoletti (2011) in his comparative study between $L$. plumulosus and Tiburonella viscana pointed out that the most important requirement for the choice of amphipod L. plumulosus is the ammoniacal nitrogen content; also, the fact that the mortality rate is not affected with the differences of grain size of sediments, the euryhaline characteristic of these organisms, and the possibility of growing, in laboratorial conditions, render this organism quite convenient for toxicity tests.

The objective was to assess the quality of sediments from the Jundiaí and Potengi Rivers, by the use of toxicity tests with the amphipod Leptocheirus plumulosus, sediments were from 4 sites, in 4 different months along 2011.

\section{MATERIALS AND METHODS}

\section{Sampling}

Sediment samples were collected for 4 months from July to October 2011 at four stations to determine toxicity and organic matter content (Figure 1). One sample per station $(3,4 \mathrm{Kg})$ was collected for toxicity tests, on the shore of the estuary, during low tide, in places with less than $70 \mathrm{~cm}$ depth of water, by using plastic scoop; the samples were stored in $1 \mathrm{~L}$ polyethylene recipients and preserved in coolers with ice during field work. In the laboratory they were kept at $4^{\circ} \mathrm{C}$ in refrigerator. Two stations are farther from the estuarine mouth (P1 in Macaíba City; P2 near the Guarapes River), and other two are closer to the mouth (P3, near the Igapó Bridge; P4, near Canto do Mangue) (Figure 1). The samples were always collected during neap tide, to avoid variability in the environmental physico-chemical parameters that occur due to the tides, once they reach all the stations twice a day during high tide. The sampling hours were defined according to the information about tides from Natal harbor provided by the Navy Hydrography Board of Brazil (DHN, 2011).

For the toxicity analyses, the samples were transported to the Ecotoxicology Laboratory at Federal University of Rio Grande do Norte (UFRN) and refrigerated until analysis according to ABNT NBR 15638/2008.

\section{Physical-chemical parameters}

During sediment collection, physicochemical parameters, including dissolved oxygen (DO), $\mathrm{pH}$, salinity and temperature, were determined in the field using a refractometer, oximeter and portable $\mathrm{pH}$ meter. The results were then compared with class I of the Brazilian federal standards for brackish water (CONAMA, 2005).

\section{Determination of organic matter content}

To determine the organic matter content, the samples were dried in a lyophilizer. Ten grams of each sample were then placed in crucibles and heated in a muffle furnace for 6 hours at $400^{\circ} \mathrm{C}$. The differences between the initial and final weights were then calculated (Lima et al., 2010).

\section{Ecotoxicological tests}

Acute toxicity tests of the estuarine sediments were conducted based on ABNT NBR 15638/2008 in the Laboratory of Ecotoxicology - ECOTOX at the Department of Oceanography and Limnology of UFRN.

Juvenile L. plumulosus (Amphipoda-Crustacea), measuring between 500 and $700 \mu \mathrm{m}$, were used as test organisms. During the tests, the samples received uniform, continuous illumination and aeration. For each sample, 20 organisms were added to each recipient using pipettes. At the same time, the procedure was conducted with the control sediment, which is the sediment used for organisms' culture from the estuary of Galinhos/RN. Before the test, particles larger than $1.0 \mathrm{~cm}$ were manually removed according to ABNT NBR 15638/2008. Samples from each station were tested in quadruplicate plus including the control. So the quadruplicates ( 80 organisms) and the control (20 organisms) totalized 100 organisms per station (sampling point). The test lasted for 10 days while the effect on survival was analyzed.

The air flow, temperature, salinity, DO and $\mathrm{pH}$ were checked in the water of each test flask daily. The surviving L. plumulosus were visualized and counted after sieving the sediment at the end of the test.

\section{Statistical analysis}

Before the statistical analysis the homoscedasticity (homogeneity of variances) of the data was verified through the Levene test. For the data that did not show homoscedasticity, the transformation of the square root of the arcosene was applied, so that they became homoscedastic (ABNT NBR 15638 , 2008). The calculation was performed through Microsoft Excel 2007 software. The results were treated using the " $\mathrm{t}$ " test for bioequivalence and bioequivalence constant $(\mathrm{B}=0.80)$, according the current procedure at the ECOTOX/UFRN. The statistical tests were carried out with the TOXSTAT program, Version 3.5 (1995). After statistical analysis, the samples were classified as "toxic" or "nontoxic", compared to the control.

\section{RESULTS}

The values of the physicochemical parameters of the water from the estuary and the organic matter in the sediment are shown in Table 1. These data and information on temperature and precipitation are shown in Figure 2. Water temperatures ranged from 26.6 to $29.1^{\circ} \mathrm{C}$ and salinity from 4 to $35 \%$. Temperature and salinity increased toward 


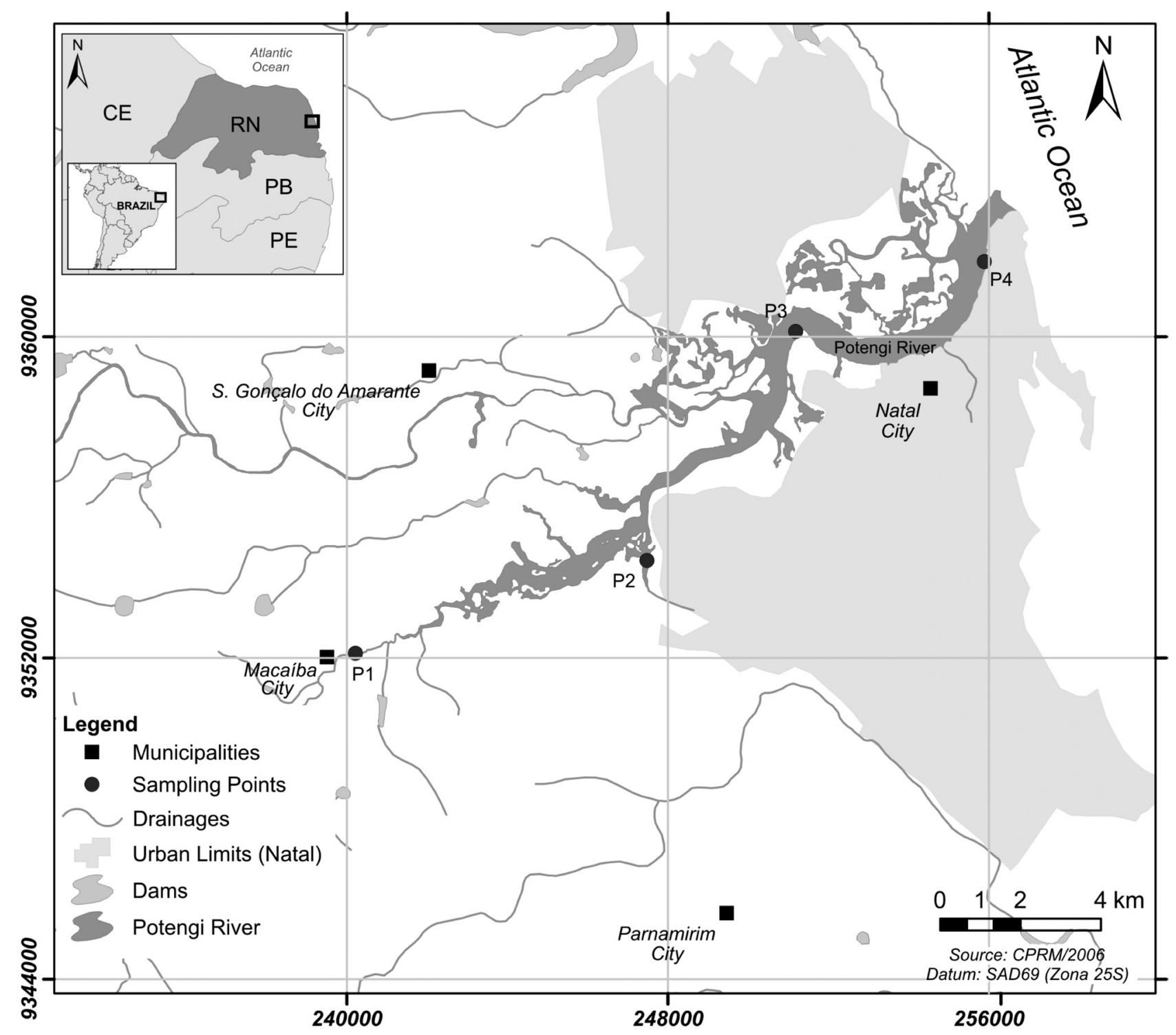

Figure 1 - Location of the sediment collection sites.

the mouth of the estuary (Figure 2). For pH, water from all stations met the standards established for class I brackish water from CONAMA RESOLUTION 357/2005, which is 6.5-8.5. Dissolved oxygen values lie between $3.5 \mathrm{mg} \mathrm{L}^{-1}$ (station 3) and $6.0 \mathrm{mg} \mathrm{L}^{-1}$ (station 4), which may indicate some change in environmental conditions. The lowest and higher values of organic matter were 0.32 (station 4) and 10.43 (station 2), respectively.

Table 2 displays the results from test and control survival, as well as ecotoxicological results (toxic or non-toxic). In July, with the exception of Station 1, which sediment showed toxicity, all other samples were classified as non-toxic to $L$. plumulosus. In August and September, none of the samples were toxic. In October, only the sample from Station 3 (Igapó) was classified as toxic. This indicates a good to fair quality for the studied sediments and is the contrary of that observed by previous studies. Therefore, sediments from P1 and P3 were toxic once, whereas sediments from $\mathrm{P} 2$ and $\mathrm{P} 4$ were not toxic.

\section{DISCUSSION}

Station 1, located near the urban center of Macaíba City, had considerable human inhabitance, with scarce mangrove forest; the sediment is composed mainly of clay siltic fractions with debris from human activities. According to Souza (2017), this area is affected by the Industrial District of Macaíba (DIM), which includes 20 industries and more industries in the Advanced Industrial Center (CIA), and also receives the disposal of effluents, often without adequate prior treatment, from domestic sewage, from immunizers, from shrimp farms, as well as the disposal of contaminants from agricultural areas. The DO values were low and below the minimum limit established for class I brackish water by CONAMA Resolution 357/2005, which is $5 \mathrm{mg} \mathrm{L}^{-1}$; however low levels of DO occur naturally in this kind of waterbody. The lowest salinity is probably related to the lowest tidal influence, the input of sewage sludge, and the input of freshwater from groundwater. Ecotoxicological tests are shown in Table 2. Only July was considered statistically toxic. 
Table 1: Physicochemical parameters in water (in situ measurements) and organic matter content in the sediments of the estuary of Potengi River.

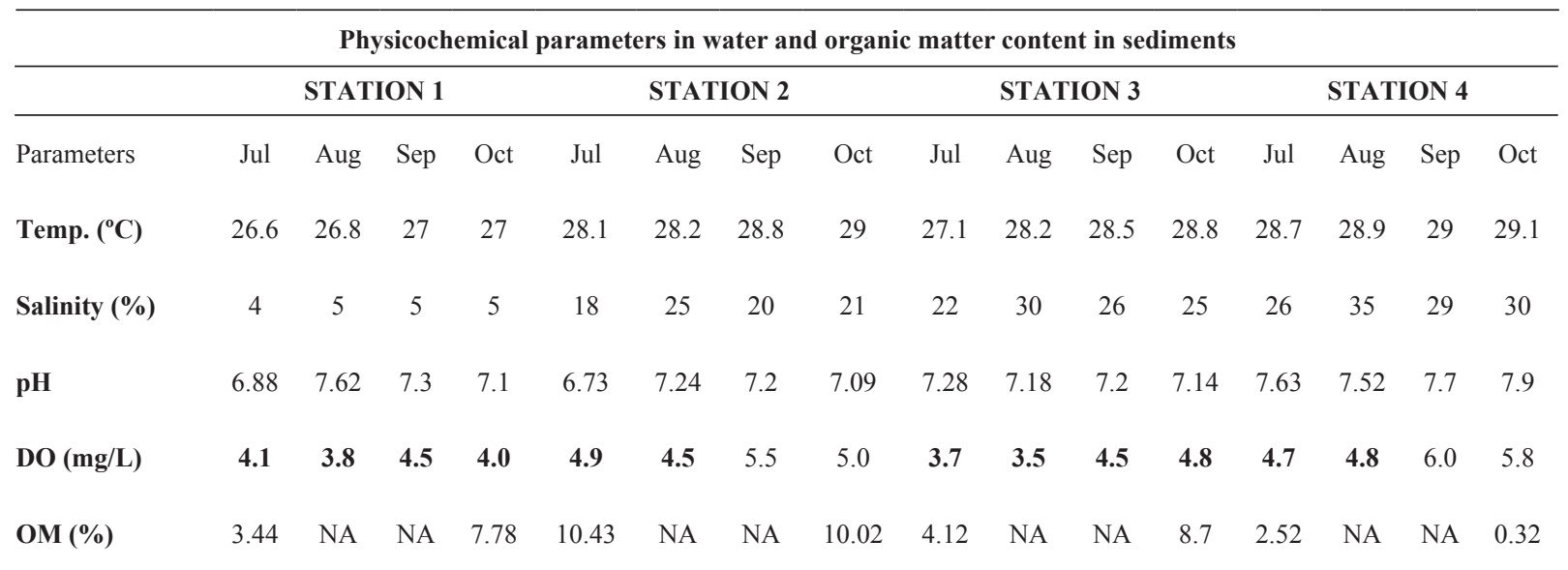

Temperature (Temp.); Dissolved Oxygen (DO); Organic Matter (OM); NA: Not analyzed; in bold: values lower than the values established in the CONAMA 357/05 resolution;
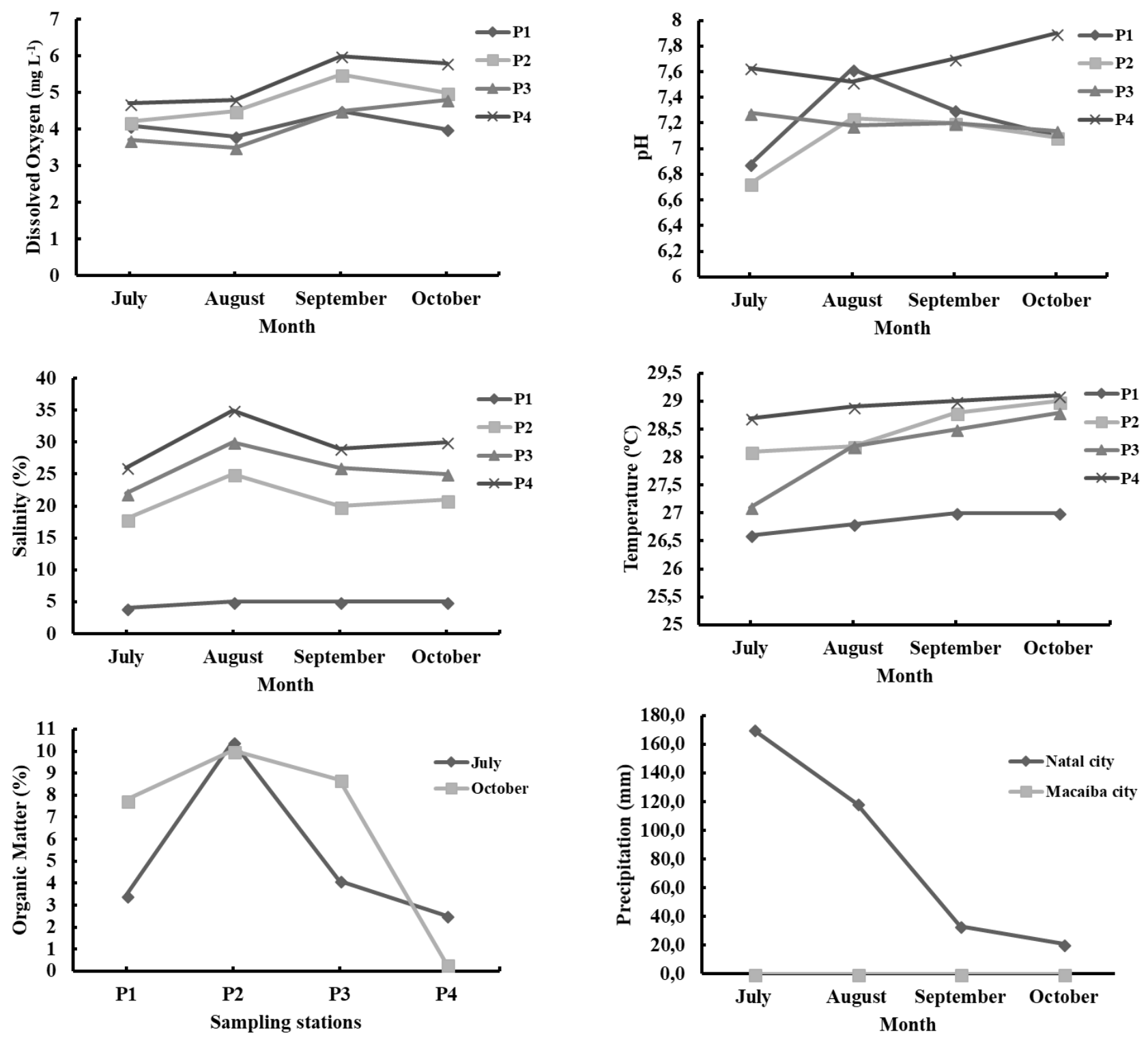

Figure 2: The physical and chemical parameters of the environment and rainfall in 2011 (source of rainfall data: EMPARN). Dissolved oxygen in mg/ $\mathrm{L}^{-1}$; salinity in $\%$; temperature in ${ }^{\circ} \mathrm{C}$; organic matter in $\%$. 
Station 2 (Guarapes) had the lowest percentage of human occupation in the estuary vicinities, and it had the largest area of preserved mangrove forest compared to the other sampling stations. The sediment sample had a predominant silt clay fraction, with high amount of roots and leaves from mangrove. The tidal influence caused a considerable increase in the salinity of the estuarine waters (Table 1 and Figure 2). The increased DO might have also resulted from this tidal influence and the contribution of water from the Guarapes River; however, two of the DO concentrations were below the values established in Resolution 357/05; these values are still considered normal for estuarine regions.

As for precipitation, there was no rainfall in the city of Macaíba during the 4 months of sediment collection from this study (EMPARN, 2011), whereas precipitation decreased in Natal and ranged from $170.3 \mathrm{~mm}$ in July to $20.8 \mathrm{~mm}$ in October. The statistical analysis showed no toxicity in station 2 compared to the control (Table 2).

The station 3 (Igapó) was located in an area with considerably high human occupation close to populated areas in Natal, occupied by poor and middle-class houses, such as Quintas, Nordeste, Bom pastor and KM6 neighborhoods, on the identical sampling bank, and Igapó neighborhood, on the opposite bank. The station 3 was also located near the confluence of the Golandim and Potengi Rivers with the Jundiaí River. The sediment is mainly composed of silt and clay, with some sand and a noticeable amount of human hair, which indicates proximity with occupied areas without basic sanitation; mangrove roots and leaves were also observed. Anthropogenic pressure might contribute to the diffuse discharge of sewage from these locations towards the estuary through many channeled and unchanneled streams in the adjacent mangrove area. Precipitation decreased over the period. The water of this station was characterized by higher salinity (between 22 and $30 \%$ ), when compared to the waters from stations1 and 2, located upstream; DO was below the limit established by resolution 357/05 in all months studied with an average of $4.1 \mathrm{mg} \mathrm{L}^{-1} \mathrm{O}_{2}$, which may reinforce the hypothesis of anthropogenic influence in the area. Regarding toxicity (Table 2), the statistical analysis showed toxicity in October

The station 4 (Canto de Mangue) consisted of the most populated site near the port of Natal, with a constant flow of boats and near the neighborhoods of Santos Reis, Rocas and Ribeira, which are urbanized areas. Station 4 also presented problems related to sewage discharge that reached the river through channeled and unchanneled streams. The sediment is sandy with fragments of shelves. During July and August, DO was below the limit established by the resolution, which is $5 \mathrm{mg} \mathrm{L}^{-1}$, but had the highest mean DO of the four stations studied $\left(5.3 \mathrm{mg} \mathrm{L}^{-1} \mathrm{O}_{2}\right)$, which was most likely related to proximity to the ocean. These results were corroborated by the observed salinity values, which were the highest among the sampled sites (between 26 and 35\%), although the measures were performed at low tide. In the ecotoxicological tests, according to the statistical analyses, the sediment from this site was not toxic during the sampling period.

The non-toxic nature of the sediments from station 4 can be explained because the organic matter levels were lower (Table 1). Low OM contents show lower amounts of ligands to the contaminants, thus these sediments have lower abilities to retain chemical substances. This can reduce the transfer of contaminants from the sediment to organisms. Furthermore, proximity to the ocean also allows a greater flow of salt water, which helps to turn over and dilute contaminants in the sediment. Station 2 was not-toxic to organisms, which can be explained by its location in a more preserved mangrove area, with the less urbanized area among the 4 sampling points

Stations 1 and 3, which sediments were toxic in July and October, respectively, were located in urbanized areas of Macaíba and Natal and showed low concentrations of DO (Table 1). We can also observe during the months studied that there was no precipitation in Macaíba city, while in Natal city the pluviometry decreased from July to October.

Tables 3 and 4 present environmental data on the studied area reported in previous works, where the point $\mathrm{P} 6$ of Guedes (2003) and point M5 of Sindern et al. (2007) are located on the same spot of the station 1 of this study; the PO4 from Sindern et al. (2007) is the same as station 4 location of this study; the 4 points of the study of Lopes et al. (2013) are the same four stations of this study; stations 1,2, 3 and 4 from the present study correspond to points $3,4,7$, and 9 , respectively, from Souza et al. (2016) and Souza (2017). Tables 3 and 4 include data of metals and physicochemical parameters from Souza et al. (2016) and Souza (2017) respectively. Table 4 also shows the sediment quality guidelines (SQGs) proposed by Long et al. (1995). These tables display the physical and chemical parameters of water (Table 3) and the levels of heavy metals in the estuary (table 4). The values that lie between the ERLERM levels proposed by Long et al. (1995) are highlighted in bold and underlined.

The data in table 3 indicate, through the physical and chemical parameters, the anthropogenic influence

Table 2: Test survival (\%) / control survival (\%) and ecotoxicological results (toxic or non-toxic) of sediments from 4 sites, in 4 different months along 2011, with Leptocheirus plumulosus.

\begin{tabular}{lcccc}
\hline \multicolumn{3}{c}{ All data are normal and homoscedastic after arcsine transformation. Bioequivalence, R=0.80. } \\
\hline Samples & July & August & September & October \\
Station 1 & $53.75 / 95$ Toxic & $97.5 / 91,25$ N. Toxic & $93.75 / 100$ N. Toxic & $88.75 / 96,25$ N. Toxic \\
Station 2 & $82.5 / 95$ N. Toxic & $88.75 / 96,25$ N. Toxic & $91.25 / 100$ N. Toxic & $97.5 / 100$ N. Toxic \\
Station 3 & $71.25 / 95$ N. Toxic & $86.25 / 91,25$ N. Toxic & $80 / 100$ N. Toxic & $71.25 / 100$ Toxic \\
Station 4 & $93.75 / 92,5$ N. Toxic & $87.5 / 91,25$ N. Toxic & $90 / 100$ N. Toxic & $97.5 / 100$ N. Toxic \\
\hline
\end{tabular}


Table 3. Data from previous studies of physical and chemical parameters in fluvial and estuarine waters of the Jundiai river and Potengi estuary. A: Guedes (2003); B: Sindern et al. (2007); C: Lopes et al. (2013); D: Souza (2017).

\begin{tabular}{|c|c|c|c|c|c|c|c|c|c|c|c|c|c|c|c|c|}
\hline & \multicolumn{4}{|c|}{ Station 1} & \multicolumn{4}{|c|}{ Station 2} & \multicolumn{4}{|c|}{ Station 3} & \multicolumn{4}{|c|}{ Station 4} \\
\hline & A & B & $\mathrm{C}$ & $\mathrm{D}$ & $\mathrm{A}$ & B & $\mathrm{C}$ & $\mathrm{D}$ & A & B & $\mathrm{C}$ & $\mathrm{D}$ & A & B & $\mathrm{C}$ & $\mathrm{D}$ \\
\hline Salinity (\%) & 0.13 & - & - & 12 & - & - & - & 29.6 & - & - & - & 33 & - & - & - & 34 \\
\hline $\mathrm{pH}$ & 7.99 & - & 6.85 & 7.27 & - & - & 6.9 & 7.10 & - & - & 7.2 & 7.35 & - & - & 7.6 & 7.95 \\
\hline $\mathrm{DO}\left(\mathrm{mg} \mathrm{L}^{-1} \mathrm{O}_{2}\right)$ & 0.78 & - & 9.6 & 4.30 & - & - & 5.6 & 5.77 & - & - & 3.2 & 5.61 & - & - & 6.75 & 5.68 \\
\hline Cond. $(\mathrm{mS} / \mathrm{cm})$ & 2068.85 & 1.51 & 896.69 & - & - & - & 38323.0 & - & - & - & 16019.87 & - & - & 38.60 & 48508.25 & - \\
\hline Redox (mV) & - & 50 & - & - & - & - & - & - & - & - & - & - & - & -296 & - & - \\
\hline Nitrite $(\mathrm{mg} / \mathrm{L})$ & 0.83 & 0.02 & - & - & - & - & - & - & - & - & - & - & - & $<0.02$ & - & - \\
\hline Ammonia $(\mathrm{mg} / \mathrm{L})$ & 0.86 & 1.0 & - & - & - & - & - & - & - & - & - & - & - & 30.0 & - & - \\
\hline $\mathrm{DBO} 5\left(\mathrm{mg} / \mathrm{L} \mathrm{O}_{2}\right)$ & 6.86 & - & - & - & - & - & - & - & - & - & - & - & - & - & - & - \\
\hline $\begin{array}{c}\mathrm{DQO} \\
\left(\mathrm{mg} / \mathrm{L} \mathrm{O}_{2}\right)\end{array}$ & 31.48 & - & - & - & - & - & - & - & - & - & - & - & - & - & - & - \\
\hline
\end{tabular}

Table 4. Data from previous studies of metal $(\mathrm{mg} / \mathrm{Kg}$ ) and total organic carbon - TOC (\%) concentrations in fluvial and estuarine sediments of the Jundiai river and Potengi estuary. A: Guedes (2003); B: Sindern et al., (2007); C: Lopes et al., (2013); D; Souza et. al., (2016); ERL/ERM: Guideline values from Long et al., (1995).

\begin{tabular}{|c|c|c|c|c|c|c|c|c|c|c|c|c|c|c|c|c|c|c|}
\hline & \multicolumn{4}{|c|}{ Station 1} & \multicolumn{4}{|c|}{ Station 2} & \multicolumn{4}{|c|}{ Station 3} & \multicolumn{4}{|c|}{ Station 4} & \multicolumn{2}{|c|}{ Guidelines } \\
\hline & $\mathrm{A}$ & B & $\mathrm{C}$ & $\mathrm{D}$ & $\mathrm{A}$ & B & $\mathrm{C}$ & $\mathrm{D}$ & A & B & $\mathrm{C}$ & $\mathrm{D}$ & $\mathrm{A}$ & B & $\mathrm{C}$ & $\mathrm{D}$ & ERL & ERM \\
\hline $\mathrm{Cd}$ & n.d. & 0.017 & 0.4 & 0.12 & - & - & 0.6 & 0.38 & - & - & 0.6 & 0.37 & - & 0.073 & $\underline{1.2}$ & 0.36 & 1.2 & 9.6 \\
\hline $\mathrm{Cu}$ & $\underline{61.0}$ & 6.0 & $\underline{36.8}$ & 17.9 & - & - & 8.8 & 3.08 & - & - & 5.2 & 1.82 & - & 28.4 & 20.6 & 0.42 & 34 & 270 \\
\hline $\mathrm{Pb}$ & $\underline{48.0}$ & 4.00 & $\underline{182}$ & 3.05 & - & - & 30 & 3.92 & - & - & 28 & 3.12 & - & 11.00 & $\underline{52}$ & 2.24 & 46.7 & 218 \\
\hline $\mathrm{Cr}$ & 54.00 & 17.3 & 22.4 & 0.26 & - & - & 24 & 0.93 & - & - & 20.4 & 0.51 & - & 30.0 & 20.6 & 0.42 & 81 & 370 \\
\hline $\mathrm{Ni}$ & $\underline{39.0}$ & 12.6 & 10 & 2.31 & - & - & 12 & 4.14 & - & - & 12 & 2.18 & - & 15.4 & 16 & 1.22 & 20.9 & 51.6 \\
\hline $\mathrm{Zn}$ & 143.0 & 11.0 & 86 & 6.30 & - & - & 48 & 14.46 & - & - & 38 & 13.23 & - & 62.7 & 118 & 1.82 & 150 & 410 \\
\hline As & n.d. & 1.50 & - & & - & - & - & & - & - & - & & - & 2.37 & - & & 8.2 & 70 \\
\hline $\mathrm{Ag}$ & - & 0.023 & - & & - & - & - & & - & - & - & & - & 0.12 & - & & 1.0 & 3.7 \\
\hline $\mathrm{Hg}$ & $\underline{0.163}$ & 0.003 & - & & - & - & - & & - & - & - & & - & 0.023 & - & & 0.15 & 0.71 \\
\hline OM (TOC) & 8.31 & 0.29 & 7.78 & & - & - & 10.4 & & - & - & 8.7 & & - & 1.22 & 2.52 & & - & - \\
\hline
\end{tabular}

Metal concentration in $\mathrm{mg} / \mathrm{Kg}$; total organic carbon in \%; n.d.= non-detected; - = non-analyzed. Guidelines: $<$ ERL (effects range-low) - conditions in which the effects would be rarely observed; ERL-ERM (Probable Effects Range) - conditions in which effects would occur occasionally; > ERM (effects range-median) - conditions in which effects would often occur.

on the stations at which samples were collected for the ecotoxicological tests. According to Guedes (2003) the point 6 (which is equivalent to station1 of this study) presented higher values than the allowed by the legislation in the parameters ammoniacal nitrogen and BOD, as well as the highest levels of nitrite and nitrate; to the author, these parameters analyzed in water confirmed the impact of anthropogenic activity in the Jundiaí River. To Sindern et al. (2007), the samples obtained in PO4 (which is equivalent to the station 4 of this study) are clearly affected by wastewater and, consequently, can be taken to investigate the anthropogenic influence, while M5 (Station 1) can be anthropogenically affected.

Lopes et al. (2013) noticed an increase in $\mathrm{pH}$ and conductivity between the city of Macaíba and the mouth of the estuary which is also evident by the increase in salinity; the authors also identified that the levels of dissolved oxygen at Guarapes (station 2) and Igapó (station 3) are lower than the levels found in Macaíba (station 1) and Canto do Mangue (station 4). Already in the work developed by Souza (2017) the area of station 1 showed the lowest levels of DO.

According to table 4 the levels of the metals $\mathrm{Cu}, \mathrm{Pb}, \mathrm{Ni}$, $\mathrm{Hg}$ in station 1, in previous studies showed values within the range ERL-ERM of the guideline proposed by Long et al. (1995) which indicates a range of possible adverse effects to organisms, that would occasionally occur; this could explain the fact that the effect of toxicity have occurred only in the month of July. The levels of $\mathrm{Cd}$ and $\mathrm{Pb}$ in station 4 are also in these levels of possible adverse effects, but the sediments of this station did not show toxicity to L. plumulosus. On the other hand, in the sediments from station 3 , which showed toxicity in October, no metal values exceeded the ERL range. These data highlight the importance of toxicity studies, since the estuary has been presenting probable levels of adverse effects for several years, characterizing it as a moderately contaminated environment as already identified in works carried out by Buruaem (2013), Souza et al. (2016) and Souza (2017). McGee et al. (2004) highlight the difficulty in establishing the cause and effect with chemical mixtures, where a likely explanation, to the authors, is that unmeasured contaminants may be contributing to toxicity.

Souza et al. (2016) used geochemical and toxicity data integrated, through cluster analyses (CAs), with the Euclidean distance and the Ward's method, as well as factor analysis with data extracted with the principal component analysis 
(FA-PCA). The data matrix used for these analyses was comprised of the results on OM, muds, Nitrogen, Phosphorus, and metals ( $\mathrm{Fe}, \mathrm{Mn}, \mathrm{Cd}, \mathrm{Cr}, \mathrm{Cu}, \mathrm{Pb}, \mathrm{Ni}, \mathrm{Zn}$ ) concentrations, amphipod mortality, reduction in copepod fecundity, and the abnormal development rate of sea-urchin embryos. According to the authors through the results of FA-PCA, it was possible to identify that in the rainy season the first factor (F1) showed associations between nitrogen, $\mathrm{Cr}, \mathrm{Cu}, \mathrm{Pb}, \mathrm{Zn}$ and mortality of amphipods; in turn the second (F2) showed positive correlations with nitrogen, $\mathrm{Cr}, \mathrm{Cd}, \mathrm{Ni}, \mathrm{OM}$, and sludge and negative correlations with $T$. viscana mortality and abnormal development of the sea urchin embryo. The factor 3 (F3) showed an association in $\mathrm{Fe}, \mathrm{Cu}, \mathrm{Ni}, \mathrm{Pb}$ and phosphorus, which, according to the authors, indicate that these elements belong to a common contaminant source, and that the fecundity of the copepods correlated negatively with this factor. According to the study by Souza et al. (2016) the second factor (FA-PCA) analyzed in the dry season explained $22.01 \%$ of the variances and showed association between nitrogen, OM, muds, Cr, $\mathrm{Cd}, \mathrm{Pd}, \mathrm{Ni}$ and L. plumulosus mortality, providing evidence human causes of environmental degradation and its effects.

In this study L. plumulosus presented acute toxicity in a few sampling stations, which is similar to the data found by Souza (2017); in this same estuary the author observed toxicity to L. plumulosus in only 3 points, the $\mathrm{P} 8$ station was toxic in the rainy season and the stations P5 and P10 in the dry period. According to the author, the chronic toxicity tests were more sensitive than the acute tests.

McGee et al. (1999) also used L. plumulosus in Chesapeake Bay, Maryland, USA, to evaluate the toxic effects of sediment. At some sampling station sites, the authors identified a negative relationship between the survival of organisms and metals associated with the sediment, such as cadmium and copper. In the present study, there was also a probable relationship between the survival of organisms at the sampling stations (Table 2) and the concentrations of metals, such as copper, zinc and lead reported in previous studies (see Table 3).

Sampling points in the study by Buruaem et al. (2013) are very close to the stations of our study. The authors used the Tiburonella viscana amphipod for acute toxicity tests and Copepod Nitocra sp for chronic toxicity tests. They observed toxicity at points 1 and 2 (PRO1 and PRO2) in two trials and toxicity at points 3 and 4 (PRO3, PRO4) for chronic toxicity test, indicating that points 1 and 2 are degraded and points 3 and 4 are moderately degraded. In turn, according to Souza et al. (2016), the results indicate that the sediments from the JPE present some degree of degradation. These sediments are toxic and enriched by metals and nutrients; for the author this situation is produced by a combination of natural sources and human activity.

\section{CONCLUSION}

This study reveals that the sediments of the Potengi and Jundiaí estuaries have a good quality, which differs from the other studies of ecotoxicology carried out in this same estuary that classifies it as toxic environment. Sediment toxicity was observed in urbanized areas that presented lower OD levels and significant concentrations of metals, as observed in an earlier study, which may corroborate data found in the literature.

The importance of the tides in the reduction of possible toxic effects was also observed, since the station near the city of Natal showed no toxicity as expected even though it was a densely urbanized area. Since that this study and other authors report levels of contamination and toxicity to organisms in this estuary, we emphasize that further studies on sediment toxicity are needed at these and other points in the Potengi / Jundiaí estuary, using a larger spatial and temporal distribution to identify temporal variations and to evaluate the effects of contaminants observed at low concentrations, as well as analyzes of new parameters in water and sediments, toxicological tests with a greater variety of organisms and studies on the bioaccumulation of contaminants in organisms.

\section{ACKNOWLEDGEMENTS}

This work was conducted with financial support from National Council for Scientific and Technological Development - $\mathrm{CNPq}$, as follows: master's scholarship for the first author process 554035/2010-3; research productivity scholarship to R.F.S. process 311221/2015-7.

\section{REFERENCES}

ARAÚJO, R. P. A., SHIMIZU, G. Y., BOHRER, M. B. C. \& JARDIM, W. 2008. Avaliação da qualidade de sedimentos In: Zagatto, P. A.; Bertoletti, E., (ed) Ecotoxicologia aquática Princípios e Aplicações. São Carlos, Brasil: RiMa, pp. 293-326.

ABNT - Associação Brasileira de Normas Técnicas. 2008. Qualidade da água - Determinação da toxicidade aguda de sedimentos marinhos ou estuarino com anfípodos. NBR 15638, Brazil.

BERTOLETTI, E. 2011. A Escolha do Anfípodo Bentônico para Ensaios Ecotoxicológicos com Sedimentos Marinhos. J. Braz. Soc. Ecotoxicol. 6(1): 1-7. https://doi: 10.5132/jbse.2011.01.001

BRITO, G. Q., MOURA, M. F. V., CRUZ, A. M. F., ARAÚJO, E.G., \& VIEIRA, M. F. P. 2008. Avaliação de Risco à Saúde Humana por Exposição ao Cobre, Chumbo, Cromo, Zinco e Cádmio presentes no Sururu (Mytella falcata) coletados no Estuário do Rio Potengi, Natal/RN. Química no Brasil, 2: 55-59.

BURUAEM, L. M.; ARAUJO, G. S.; ROSA, P. A.; NICODEMO, S. C.; PORTO, V. F.; FONSECA, J. R; CRUZ, J. V., MEDEIROS, G. F. \& ABESSA, D. M. S. 2013. Assessment of sediment toxicity from the Areia Branca off-shore harbor and the Potengi River estuary (RN), Northeastern Brazil. Pan-American Journal of Aquatic Sciences, 8(4):312-326.

CONAMA No 357/2005 - "Dispõe sobre a classifcação dos corpos de água e diretrizes ambientais para o seu enquadramento, bem como estabelece as condições e padrões de lançamento de efluentes, e dá outras providências.” Legislation date: DOU $17 / 03 / 2005$.

CONAMA No 454/2012 - "Estabelece as diretrizes gerais e os procedimentos referenciais para o gerenciamento do material a ser dragado em águas sob jurisdição nacional.” Legislation date: 
DOU 01/11/2012.

DHN - Diretoria de Hidrografia e Navegação da Marinha do Brasil, 2011, Natal, HTTP://www.mar.mil.br/dhn/chn/tabuas/.

EMERENCIANO, D. P., SILVA, H. F. O., CARVALHO, G. C., CRUZ, A. M. F. \& MOURA, M. F. V. 2008. Análise da ocorrência de metais: bário, cádmio, chumbo, cobre, cromo, estanho, níquel e zinco, em mexilhão (Anomalocardia brasiliana) coletados no Estuário Potengi/Jundiaí - RN. Revista Publica, 4: 1-9.

EMPARN. Empresa de Pesquisa. Agropecuária do Rio Grande do Norte. Monitoramento Pluviométrico.2011.http://187.61.173.26/ monitoramento/monitoramento.php

GUEDES, J. A., 2003. Diagnóstico geoquímico-ambiental do Rio Jundiaí nas imediações da cidade de Macaíba/RN. MSc. Dissertation. Universidade Federal do Rio Grande do Norte, Natal, 130p.

LIMA, R. F. S., GUEDES, J. A., BRANDÃO, P.R.G., SOUZA, L.C. \& PETTA, R. A. 2010. The influence of the specific surface area of particles on trace-elements adsorption by bottom sediments: a case study in the surroundigs of Macaíba City, Rio Grande do Norte State, Brazil In: Medical Geology in Brazil. Rio de Janeiro, Brazil: Geological Survey of Brazil, pp. 200-206.

LOPES, R.B., SOUZA, R.F., MOURA, M.F.V., GUEDES, J.A., MEDEIROS, G.F. \& FERREIRA, D.M. 2013. Contaminação por Metais Pesados no Sedimento e no Caranguejo-Uça, Ucides cordatus (Linnaeus, 1763), no Estuário dos Rios Jundiaí e Potengi, RN/Brasil. In: Ximenes, M.F.F.M. e SOUZA, R.F, Meio Ambiente e Saúde Humana: Práticas, Vivências e Saberes. Natal, Brazil: EDUFRN, pp.167-190. ISBN 978-85-425-0002-8

LONG, E. R., MACDONALD, D. D., SMITH, S. L. \& CALDER, F. D. 1995. Incidence of Adverse Biological Effects Within Ranges of Chemical Concentrations in Marine and Estuarine Sediments. Environ. Manage. 19(1): 81-97. https://DOI:10.1007/ BF02472006

LOTUFO, G. R., FARRAR, J. D., DUKE, B. M., \& BRIDGES. T. S. 2001. DDT Toxicity and Critical Body Residue in the Amphipod Leptocheirus plumulosus in Exposures to Spiked Sediment. Arch. Environ. Con. Tox., 41:142-150. https:/DOI: 10.1007/ s002440010231

MANYIN, T. \& ROWE, C. L. 2006. Chronic exposure of Leptocheirus plumulosus to Baltimore Harbor sediment: Bioenergetic and population-level effects. Mar. Environ. Res., 62: 116-130. https://DOI:10.1016/j.marenvres.2006.03.006

MCGEE, B. L., WRIGHT, D. A. \& FISHER, D. J. 1998. Biotic Factors Modifying Acute Toxicity of Aqueous Cadmium to Estuarine Amphipod Leptocheirus plumulosus. Arch. Environ. Con.Tox., 34: 34-40. https://DOI:10.1007/s002449900283
MCGEE, B. L., FISHER, D. J., YONKOS, L. T., ZIEGLER, G. P., \& TURLEY, S. D. 1999. Assessment of sediment contamination, acute toxicity, and population viability of the estuarine Amphipod Leptocheirus plumulosus in Baltimore Harbor, Maryland, USA. Environ. Toxicol. Chem., 18(10): 2151-2160. ISSN: 0730-7268 MCGEE, B. L., FISHER, D. J., WRIGHT, D. A.; YONKOS, L. T; ZIEGLER, G. P.; TURLEY, S. D. FARRAR, J. D.; MOORE, D. W. \& BRIDGES, T. S. 2004. A field test and comparison of acute and chronic sediment toxicity tests with the estuarine amphipod Leptocheirus plumulosus in Chesapeake Bay, USA. Environ. Toxicol. Chem., 23(7): 1751-1761. https://DOI:10.1897/03-326

SILVA, C. A. R., SMITH, B. D. \& RAINBOW, P. S. 2006. Comparative biomonitors of coastal trace metal contamination in tropical South America (N. Brazil). Mar. Environ. Res., 61: 439455. https://DOI:10.1016/j.marenvres.2006.02.001

SILVA-NICODEMO, S. C. T. 2010. Diagnóstico ecotoxicológico dos efluentes lançados no complexo estuarino do Jundiaí/ Potengi, Natal/RN. M.Sc. Dissertation. Universidade Federal do Rio Grande do Norte, Natal, 96p.

SINDERN, S, LIMA, R. F. S., SCHWARZBAUER, J. \& PETTA, R. A. 2007. Anthropogenic heavy metal signatures for the fast growing urban area of Natal (NE-Brazil). Environ. Geol. 52: 731-737. https://doi.org/10.1007/s00254-006-0510-z

SOUZA, I. S.; ARAÚJO, G. S.; CRUZ, A. C. F.; FONSECA, T. G.; CAMARGO, J. B. D. A.; MEDEIROS, G. F. \& ABESSA, D. M. S. 2016. Using an integrated approach to assess the sediment quality of an estuary from the semi-arid coast of Brazil. Mar. Pollut. Bull., 104: 70-82. https://doi.org/10.1016/j. marpolbul.2016.02.009

SOUZA, I. S. 2017. Avaliação integrada da qualidade dos sedimentos do complexo estuarino Jundiaí - Potengi, Natal/RN. PhD Thesis. Universidade Federal do Ceará, Fortaleza, 307p.

WILliAMS, J. J., DUTTON, J., CHEN, C. Y., \& FISHER, N. S. 2010. Metal (As, $\mathrm{Cd}, \mathrm{Hg}$, and $\mathrm{Ch}_{3} \mathrm{Hg}$ ) bioaccumulation from water and food by the benthic Amphipod Leptocheirus plumulosus. Environ. Toxicol. Chem., 29(8): 1755-1761. https:// DOI:10.1002/etc.207

YU, RI-Q. \& FLEEGER, J. W. 2006. Effects of nutrient enrichment, depuration substrate, and body size on the trophic transfer of cadmium associated with microalgae to the benthic Amphipod Leptocheirus plumulosus. Environ. Toxicol. Chem., 25 (11): 3065-3072. https://DOI:10.1897/06-029R.1

ZULKOSKY, A.M., FERGUSON, P.L. \& MCELROY, A.E. 2002. Effects of sewage-impacted sediment on reproduction in the benthic crustacean Leptocheirus plumulosus. Mar. Environ. Res., 54: 615-619. https://DOI:10.1016/S0141-1136(02)00200-3 